\title{
2. 医師の立場から
}

\author{
鈴 木 康 夫*
}

医師は患者に薬を処方し、その効果や副作用を 直接知る立場にあることから、医薬品情報の伝详 において重要な役割を果たしている。奉際に、医 師は薬事行政の責任者である国（厚生省）や製薬 会社、薬剂師そして患者と招互いに情報交換をし ているが、特に医師から患者への医薬品情報の提 供は安全にかつ効果良く服薬するために欠かすこ とはできない。服薬の最終目的は病状の改善、病 気の治瘾である。そのためには、服薬が正しくで き副作用なく継続できることが必須である。医師 は患者にどのような医薬品に関連する情報を提供 するべきかを表 1 にあげる。

\section{表 1 服薬する上で必要な情報}

1 ) 病名や病状と薬物療法の必要性

2) 薬の作用機序

3 ) 薬剂の潠択理由と同系薬剂の有無

4) 服薬方法

5 ）効果がでるまでの期間

6) 服薬期間

7 ) 重篤な副作用と頻度の多い副作用

8 ）他の薬との併用時の注意点（相互作用）

9 ) 服薬中の生活上の注意点

10) 薬の保管と管理

【病名や病状と薬物療法の必要性】

すべての症状や病気が薬物療法の対象となるわ

* 聖マリアンナ医科大学難病治療研究センター 干 216 川崎市宮前区菅生 2-16-1
けではない。食事療法など日常生活上の注意がま ず優先される場合は説明が必要である。また、発 熱や痛みの様に薬物を患者自ら必要と感じる場合 と異なり自覚症状がない高血圧、高脂血症などの 場合は、長期続くとどんな不都合が起きるのか説 明し服薬の必要性を理解してもらわないと服薬が 不規則になりやすい。

\section{【薬の作用機序】}

薬の詳しい作用機序は理解も難しいし、必要な いが、薬によっては作用機序を知ることにより副 作用に関する理解が高まる。ステロイド薬の免疫 抑制作用と感染に対する抵抗力低下やCa拮抗薬の 血管拡張作用と顔面紅潮、頭痛が良い例である。

\section{【薬剤の選択理由と同系薬剤の有無】}

降圧薬、消炎鎮痛薬、抗生物質などは同系統の 薬物が多数ある。また、同じ薬物が錠剂、徐放 剂、坐版など異なった剂型で使用できる場合もあ る。薬剂の選択にあたっては、年齢、合併症、併用 薬剂など様々な点が考慮される。どのような理由 で薬剂が選択され、他の同系統の薬剂と比べてど んな特徽があるか理解していると、安易に他の薬 剂を服用せず、きちんと服薬できる場合がある。

\section{【服薬方法】}

薬物や投与量が同じでも服薬方法が異なると効 果や副作用も異なる場合がある。食後に服用する と吸収が極めて悪くなる薬もあるが、非ステロイ ド抗炎症薬のように食直後に服用した方が、胃腸 障害が少ない場合もある。また、服薬を忘れた場 
614 薬理学研連シンポジウム

合の対処も重要である。朝忘れたら昼や夜でも 1 日 1 回服薬した方が良い場合やステロイド薬の様 に突然の服薬中止が重篤な状態を招く恐れがある 場合は必ず説明する。正しい服薬方法は薬効を十 分に引き出し、副作用を減らすのに重要である。

\section{【効果がでるまでの期間】}

薬には速効性のものと遅効性のものがある。す ぐ効くはずの薬が効かない場合は続けていても意 味がない。膠原病の発熱にステロイドを投与する と48時間以内に解熱する。熱が続けば、薬の量が 適当でないか熱の原因が別の病気である可能性が ある。また、抗りウマチ薬のように効いて来るま で2-3ケ月かかる薬は、説明しないと勝手な自 己中止につながる。

\section{【服薬期間】}

症状を抑える対症療法薬は症状が消失してしま えば継続する必要はない。例えば感染症で熱があ る場合、解熱薬で熱はすぐ下がるかもしれない が、抗生物質が効いて病原菌が消失するまでは数 日必要である。熱がなくなれば解熱薬は必要ない が、抗生物質は決められた期間服用が必要であ

る。降圧薬は中止すれば再び血圧が上がる場合が 多いし、抗りウマチ薬は慢性関節リウマチが寞解 状態となっても原則として継続する。抗甲状腺薬 は服薬後 2 ヶ 月ぐらいで症状は軽快するが、中止 できるまで平均 3 年はかかる。以上のように、症 状軽快後も継続しなければならない薬や長期服薬 が必要な薬は説明しないと自己中止が多くなる。

\section{【重篤な副作用と頻度の多い副作用】}

副作用は患者にとって最も重要な医薬品情報の 1つである。特に、放置しておくと重篤な状態に なる可能性がある副作用と重症度は低いが比較的 頻度が多くみられる副作用及び起きた場合の対処 方法は説明する必要がある。前者は直ちに中止し て医師に連絡が必要な場合が多い。後者は直ちに 漸絡を取る必要はないが、患者が知っていれば、 中止して次回受診時に相談できる。その際、副作 用の具体的な初期症状で説明した方が親切であ る。もう1つ重要な点は副作用が服薬を始めてか らどのくらいの時期に出現する事が多いかであ
る。服薬後 3 ヶ月以内に起きる副作用も多いが、 いつでも起きうる副作用もあるので、服用後に新 たな症状がみられた時、薬との関漸性を判断する のに重要な情報となる。

\section{【他の薬との併用時の注意点（相互作用）】}

薬理学的に多くの薬物相互作用が知られている が、臨床的に問題となる相互作用は具体的に薬物 名をあげて説明する。複数の医療機関から投薬を 受ける場合は、完全な医薬分業制ではないので、 患者が1つの薬局から薬を受け取ることは困難で ある。重要な相互作用がある薬物は他の医療機関 から相手の薬物が処方される可能性も念頭に置き 説明すべきである。フルオロウラシルとソリブジ ンの併用による重症血液障害が良い例である。

\section{【服薬中の生活上の注意点】}

薬効や副作用に関連する生活上の注意は説明し なければならない。降圧薬や高脂血症薬は食事療 法を並行して行えばより効果が期待できる。シク ロホスファミドの重篤な副作用である出血性膀胱 炎は水分の十分な摂取により予防が可能である。

\section{【薬の保管・管理】}

すべての薬が対象となるわけではないが、薬に よっては保管条件によってはすぐに失活してしま うものがある。例えば、ニトログリセリン舌下鉈 は、高温·多湿・光で活性を失いやすいので、茶 色い瓶に入れて数錠を持ち歩き残りは冷蔵庫に入 れて保管し、1-2ヶ月毎に新しいのと取り替え るのがよい。知らないで、活性がなくなった薬を 発作時に服用して効果がないと大変である。

【おわりに】以上のような情報を提供できれば理 想的であるが現実的には短い診療時間ではなかな か難しい。現在の医薬品添付文書に記載されてい る情報は、患者に取っては不親切である。薬に関 するすべての情報を網羅する添付文㫮的な物も必 要であるが、医師が患者に与える医薬品情報は、 副作用なく正しく服薬し病気が良くなることを目 的とした治療の一貫であり、指導的な要素を持っ ているものだと考える。現在、臨床医からみた必 要な医薬品情報を患者に提供できるコンピュータ ーシステム“メディクイック”を作成中である。 